\title{
Hormonal Control of Pancreatic Growth
}

\author{
David L. Mainz, Owen Black, and Paul D. Webster \\ From the Gastroenterology Research Laboratories, Veterans Administration \\ Hospital and Medical College of Georgia, Augusta, Georgia 30904
}

A B S T R A C T Investigations have outlined pancreatic secretory and synthetic responses to gastrointestinal hormones. However, there is little information concerning hormonal influences on pancreatic growth.

These studies were designed to examine effects of chronic administration of bethanechol and cholecystokinin-pancreozymin (CCK-PZ) on the pancreas. Male albino rats were given saline, bethanechol, $6 \mathrm{mg} / \mathrm{kg}$, or CCK-PZ, $20 \mathrm{U} / \mathrm{kg}$, intraperitoneally twice daily and killed after 5 days. The following changes were studied; pancreatic weight; RNA, DNA, and protein content; and $\left[{ }^{14} \mathrm{C}\right]$ thymidine incorporation into DNA. Bethanechol administration was associated with a $20 \%$ increase in pancreatic weight and a $33 \%$ increase in $\mathrm{mg}$ protein/ $100 \mu \mathrm{g}$ DNA. In bethanechol-treated groups, amounts of DNA/gram body weight and incorporation of $\left[{ }^{14} \mathrm{C}\right]$ thymidine into DNA were similar to controls. CCK-PZ administration was associated with a $71 \%$ increase in pancreatic weight and a $38 \%$ increase in $\mathrm{mg}$ protein/ $100 \mu \mathrm{g}$ DNA. In CCK-PZ-treated groups, amounts of DNA/gram body weight were increased by $42 \%$ and $\left[{ }^{14} \mathrm{C}\right]$ thymidine incorporation into DNA was increased by $185 \%$.

These studies indicate that bethanechol administration was associated with increases in pancreatic cell mass (hypertrophy). CCK-PZ administration was associated with increases in cell mass and cell numbers (hypertrophy and hyperplasia). This information suggests the importance of CCK-PZ in maintaining pancreatic functional integrity. Although bethanechol and CCK-PZ elicit similar secretory responses, their mode of action on the cell, at least as far as growth influences are concerned, appears to be different.

\section{INTRODUCTION}

It is well-established that pancreatic protein synthesis and secretion are initiated by feeding. Moreover, many

\footnotetext{
Received for publication 30 January 1973 and in revised form 2 April 1973.
}

of the metabolic changes observed in the pancreas after feeding can be initiated by administration of hormones of two types: neurohormones, for example acetylcholine, and gastrointestinal hormones, for example cholecystokinin-pancreozymin (CCK-PZ) ${ }^{1}$ and gastrin $(1,2)$. Pancreatic protein synthesis, RNA synthesis, and phospholipid and triglyceride synthesis are initiated after administration of these two types of hormones $(1,3,4)$.

It is well-established that some hormones exert trophic effects on their target cells as well as influencing synthesis and secretion of target cell products. The pancreats was long considered to be a stable organ lacking growth and regenerative capabilities $(5,6)$. However, Fitzgerald and co-workers have elegantly demonstrated pancreatic regeneration after cessation of ethionine administration or surgical resection of half the gland (7-9). Moreover, pancreatic hypertrophy and hyperplasia have been described in chickens and rats fed raw or uncooked soybeans (10-12). These observations, made on different experimental models, clearly indicate that the pancreas possesses growth and regenerative capabilities. On the other hand, little information is available to indicate mechanisms involved in initiation or control of these growth and regenerative processes.

The present studies were designed to study effects of chronic administration of saline, bethanechol chloride, or CCK-PZ on pancreatic weight, DNA, RNA, and protein content and $\left[{ }^{14} \mathrm{C}\right]$ thymidine incorporation into DNA. These studies indicate that primary growth influences on the pancreas are mediated via the polypeptide hormone, CCK-PZ.

\section{METHODS}

Male Sprague-Dawley rats (initial weights, 280-300 g) maintained on Purina Rat Chow (Ralston-Purina Co., St. Louis, Mo.) and water ad lib. were used for all studies. The animals were given bethanechol chloride, $6 \mathrm{mg} / \mathrm{kg}$, CCK-PZ, 20 Ivy $\mathrm{U} / \mathrm{kg}$, or physiologic saline $(0.36 \mathrm{ml})$

${ }^{1}$ Abbreviation used in this paper: CCK-PZ, cholecystokinin-pancreozymin. 
TABLE I

Effects of Chronic Administration of Saline, Bethanechol Chloride, and CCK-PZ on Pancreas of Rats

\begin{tabular}{|c|c|c|c|c|c|c|c|c|}
\hline & & & mg Panc. wt & mg Panc. wt & $\mu \mathrm{g}$ DNA & cpm & $\mu \mathrm{g}$ RNA & mg Prt. \\
\hline Treatment & Body wt & Panc. wt & g Body wt & $100 \mu \mathrm{g}$ DNA & g Body wt & $100 \mu \mathrm{g}$ DNA & $100 \mu \mathrm{g}$ DNA & $100 \mu \mathrm{g}$ DNA \\
\hline & $g$ & $m g$ & & & & & & \\
\hline Saline & $330 \pm 16$ & $909 \pm 109$ & $2.8 \pm 0.33$ & $16.3 \pm 8$ & $17 \pm 2.9$ & $189 \pm 90$ & $82 \pm 8$ & $2.1 \pm 0.38$ \\
\hline $\begin{array}{l}\text { Bethanechol, } \\
6 \mathrm{mg} / \mathrm{kg} \text { b.i.d. }\end{array}$ & $334 \pm 21$ & $1070 \pm 33 t$ & $3.2 \pm 0.27 \ddagger$ & $19.0 \pm 2 \S$ & $17.1 \pm 1.7$ & $237 \pm 140$ & $81 \pm 14$ & $2.8 \pm 0.36 \ddagger$ \\
\hline $\begin{array}{l}\text { CCK-PZ, } \\
20 \mathrm{U} / \mathrm{kg} \text { b.i.d. }\end{array}$ & $330 \pm 10$ & $1492 \pm 55 \|$ & $4.5 \pm 0.4 \|$ & $18.8 \pm 1.98$ & $24.1 \pm 2.7 \|$ & $540 \pm 231 \|$ & $91 \pm 11^{*}$ & $2.9 \pm 0.30 \|$ \\
\hline
\end{tabular}

Values are means $\pm 1 \mathrm{SD}$. These data represent results derived from three separate experiments; each experiment utilized four rats in control and four rats in experimental groups. Types of treatment are indicated in Methods. Pancreatic tissue was incubated in 25-ml Erlenmeyer flasks containing 500 mg pancreas, $2.5 \mathrm{ml}$ of tissue culture media, and $0.02 \mu \mathrm{Ci}\left[{ }^{14} \mathrm{C}\right]$-thymidine. Protein, RNA, and DNA content as well as incorporation of [14 $\left.\mathrm{C}\right]$ thymidine into DNA were determined after completion of in vitro incubation. $P$ values were determined using Student's $t$ test: $*=<0.05 ; \ddagger=<0.025 ; \S=<0.005$; $\|=<0.001$.

intraperitoneally each $12 \mathrm{~h}$ for 5 days. The doses of bethanechol chloride and CCK-PZ were derived from previous investigations (13, footnote 2$)$. Drugs or saline were administered at 8:30 a.m. and 8:30 p.m. each day. All animals received the last injection at 8:30 p.m., $12 \mathrm{~h}$ before sacrifice. Body weights were determined before and at time of study.

The following materials were used: bethanechol chloride (Urecholine), $5 \mathrm{mg} / \mathrm{cm}^{3}$ (Merck Sharp \& Dohme, West Point, Pa.); CCK-PZ (GIH Research Unit, Karolinski Institute, Stockholm, Sweden); $\left[{ }^{14} \mathrm{C}\right]$ thymidine (New England Nuclear, Boston, Mass.) ; materials for tissue culture media: MCTC-109, MEM, 100X (Microbiological Associates, Inc., Bethesda, Md.) ; calf thymus DNA and D-ribose (Nutritional Biochemicals Corp., Cleveland, Ohio) ; orcinol (Fisher Scientific Co., Pittsburgh, Pa.); diphenylamine (Eastman Organic Chemicals Div., Eastman Kodak Co., Rochester, N. Y.) ; bovine serum albumin (crystallized and lyophilized) and crystalline thymidine (Sigma Chemical Company, St. Louis, Mo.).

Treatment and incubation of tissue. Rats were killed by cervical dislocation. The pancreas was removed, fat and excess tissue trimmed, the tissue weighed on a Roller-Smith balance (Roller-Smith, Inc., Newark, N. J.), and placed in cold, oxygenated Krebs-Ringer phosphate buffer solution ( $\mathrm{pH} \mathrm{7.4).} \mathrm{The} \mathrm{tissue} \mathrm{was} \mathrm{incubated} \mathrm{in} \mathrm{25-ml} \mathrm{Erlenmeyer}$ flasks in a shaking water bath for $90 \mathrm{~min}$ at $37^{\circ} \mathrm{C}$. Each incubation flask contained $500 \mathrm{mg}$ pancreas in $2.5 \mathrm{ml}$ KrebsRinger phosphate tissue-culture medium and $0.02 \mu \mathrm{Ci}\left[{ }^{14} \mathrm{C}\right]-$ thymidine. These procedures have been described previously (14-16). At completion of in vitro incubation, the reaction was stopped by the addition to each flask of $5.0 \mathrm{ml} 2.1$ normal perchloric acid (PCA) containing $0.1 \%$ cold thymidine. The tissue was homogenized using ground-glass homogenizers and $2.0-\mathrm{ml}$ samples were taken for analysis of DNA, RNA, and protein. Extraction and washing were accomplished by use of repeated centrifugation with resuspension and vigorous stirring. The tissue pellets were washed twice with 0.7 normal PCA containing $0.1 \%$ cold thymidine, once with $20 \%$ sodium acetate in $90 \%$ alcohol, and twice with ethanol-ether $(3: 1 \mathrm{vol} / \mathrm{vol})$. These washings were performed at $4^{\circ} \mathrm{C}$. RNA was extracted in 0.3

${ }^{2}$ Webster, P. D., O. Black, and J. A. Morisset. 1973. Effect of bethanechol chloride on protein synthesis in rat pancreas. Submitted for publication. normal potassium hydroxide by incubation for $2 \mathrm{~h}$ in a shaking water bath at $37^{\circ} \mathrm{C}$. Protein and DNA were precipitated by addition of $0.065 \mathrm{ml}$ of $70 \% \mathrm{PCA}$ and $3 \mathrm{ml}$ of one normal ice-cold $\left(4^{\circ} \mathrm{C}\right)$ PCA. DNA was extracted in $3 \mathrm{ml}$ of 0.5 normal PCA by heating at $90^{\circ} \mathrm{C}$ for $20 \mathrm{~min}$. Protein was solubilized in $3 \mathrm{ml}$ of 0.3 normal potassium hydroxide by heating at $90^{\circ} \mathrm{C}$ for $20 \mathrm{~min}$. These procedures are modifications of methods developed by Schmidt and Thannhauser (17), Schneider (18), and Webster and Tyor (19) and used by us previously.

DNA was determined by the diphenylamine method using calf thymus DNA as a standard (20). RNA was determined by the orcinol method using ribose as a standard (21). Protein was determined by the biuret method using bovine serum albumin as the standard (22). Radioactivity was assayed in a Packard liquid scintillation counter (Packard Instrument Co., Inc., Downers Grove, Ill.) using a phosphor developed by Patterson and Greene (23).

\section{RESULTS}

Fig. 1 shows rates of incorporation of $\left[{ }^{14} \mathrm{C}\right]$ thymidine into pancreatic DNA. Under these conditions of in vitro incubation, incorporation was near linear for $30,60,90$, 120 , and $150 \mathrm{~min}$. Other investigators, using different tissues, have shown that thymidine nucleotide pools were small and that there was rapid equilibration between intracellular and extracellular thymidine pools (24). In addition, at concentrations of $\left[{ }^{14} \mathrm{C}\right]$ thymidine used in these experiments, no labeled $\left[{ }^{14} \mathrm{C}\right]$ thymidine triphosphate remained unincorporated in the cell (25). These observations were considered sufficient to validate the use of in vitro incubation of pancreas for short-term studies of DNA synthesis. A 90 min period of in vitro incubation was used for other experiments.

Table I shows effects of chronic administration of saline, bethanechol chloride, and CCK-PZ on body weight, pancreatic weight, DNA, RNA, and protein content. Types of treatment are expressed in the lefthand column. Body weights for all groups of animals were similar. Pancreatic weights increased $20 \%$ with 


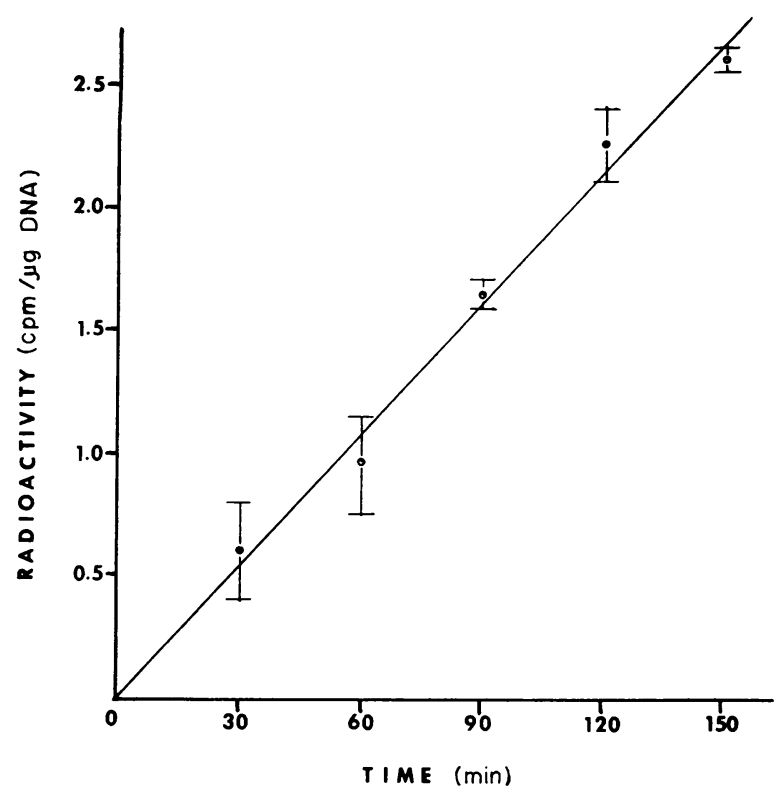

Figure 1 Rate of incorporation of $\left[{ }^{14} \mathrm{C}\right]$ thymidine into DNA by rat pancreas.

bethanechol and $71 \%$ with CCK-PZ treatment. Both increases were statistically significant when compared with saline-treated controls. Parallel changes were observed when pancreatic weights were expressed in terms of grams body weight. There was a $14 \%$ increase in bethanechol-treated groups and a $60 \%$ increase in CCK-PZ-treated groups.

Expression of pancreatic weights in terms of $100 \mu \mathrm{g}$ DNA revealed 17 and $15 \%$ increases with bethanechol and $\mathrm{CCK}-\mathrm{PZ}$ treatment. Increases in pancreatic weight could be due to either hyperplasia or hypertrophy. These increases were statistically significant. DNA content is generally considered an indicator of cell numbers. These data indicate similar increases in cell mass resulted from bethanechol and CCK-PZ treatment.

The data were next expressed in terms of micrograms DNA/gram body weight. Since DNA is an indication of cell numbers and grams body weight were constant for all groups in these experiments, expression in this form represents numbers of cells per pancreas. There were no changes in cell numbers per gram body weight when saline and bethanechol treatment groups were compared. However, there was a $42 \%$ increase in DNA content/ gram body weight with CCK-PZ administration. This indicates that CCK-PZ administration was associated with increases in numbers of pancreatic cells. The increases with CCK-PZ treatment were statistically significant.

That increases in pancreatic cell numbers or DNA content were real and associated with increased DNA synthesis was indicated by increases in $\left[{ }^{14} \mathrm{C}\right]$ thymidine incorporation into DNA. There were no differences between saline and bethanechol treatment groups in $\left[{ }^{14} \mathrm{C}\right]$ thymidine incorporation into DNA. However, there was a $185 \%$ increase in incorporation of $\left[{ }^{14} \mathrm{C}\right]$ thymidine into DNA with pancreozymin treatment. These data, along with the above described changes in cell numbers, indicate that there were increases in numbers of pancreatic cells as well as rates of DNA synthesis.

Effects of chronic administration of bethanechol chloride and CCK-PZ on pancreatic RNA and protein are expressed in the last two columns of Table I. RNA content, when expressed in terms of DNA, did not increase with bethanechol treatment. However, there was a $11 \%$ increase in RNA content with pancreozymin treatment. This increase was statistically significant. Increases of 33 and $38 \%$ were seen in protein content with bethanechol and pancreozymin treatment. The increases in protein content account for at least part of the increases in cell weight.

These data indicate that bethanechol administration was associated with increases in cell mass (hypertrophy), whereas pancreozymin treatment was associated with increases in cell mass (hypertrophy) as well as cell numbers (hyperplasia).

\section{DISCUSSION}

For many years only secretory effects of gastrointestinal hormones excited experimental interest; more recently, metabolic effects on target organs and cells have received investigative attention. It is known that gastrin and pentagastrin not only initiate hydrochloric acid secretion but also cause trophic changes in parietal cells as well as increases in $\left[{ }^{14} \mathrm{C}\right]$ amino acid and orotic acid incorporation into gastric and duodenal mucosal proteins and RNA $(26,27)$. It is recognized that CCK-PZ initiates pancreatic secretion as well as augments rates of protein synthesis, nuclear RNA synthesis, polysomal aggregation, palmitate oxidation to $\mathrm{CO}_{2}$, and triglyceride incorporation into phospholipids $(1,3,4)$.

Whether or not the pancreas possesses growth and regenerative capabilities is of considerable clinical importance. On the basis of low mitotic indices, conventional morphologists held that the pancrease possessed little growth potential (5). On the basis of autoradiographic studies, Leblond and Walker reported that the pancreas displayed no signs of cell renewal (6).

Despite these views, other lines of investigation indicated growth and regenerative capabilities were present $(7,8)$. Pancreatic hypertrophy and hyperplasia were described in poultry and rats after feeding of uncooked soybeans (11). Later it was recognized that soybeans contained a heat-labile trypsin inhibitor and that inhibition of trypsin activity in the duodenum augmented pancreatic secretion. It was suggested that the hypersecre- 
tion resulted in increased pancreatic size (10). Recent studies by Green and Lyman have shown that inhibition of trypsin and chymotrypsin activity in the duodenum augments pancreatic secretion (28). They postulate that soybean trypsin inhibitor has its effect by binding trypsin and chymotrypsin such that feedback inhibition of $\mathrm{CCK}-\mathrm{PZ}$ release from duodenal receptor cells is impaired (29). Augmented CCK-PZ release results in hypersecretion.

Fitzgerald and co-workers have studied in great detail regeneration of rat pancreas after ethionine injury or surgical resection (7-9). They demonstrated that rats fed ethionine would reconstitute the pancreas within 1-2 wk after withdrawal of the amino acid analogue. Mitotic figures and evidences of regeneration were most prevalent 4-7 days after ethionine cessation. Quantitative investigations have shown that after destruction of the pancreas with ethionine, more than $90 \%$ of acinar cells regenerate within a few weeks $(7)$.

Rothman and Wells observed increases in pancreatic size and weight after chronic administration of CCK-PZ. Morphologic examination of pancreata revealed enlargement of acinar cells. They attributed the increases in weight to increases in protein and enzyme synthesis (30). Mayston and Barrowman demonstrated that chronic administration of pentagastrin resulted in increased weight and RNA content of pancreas. However, DNA content was unchanged and DNA synthesis was not examined (31).

The data presented in our paper indicate that growth influences on the pancreas are mediated by the gastrointestinal hormone, CCK-PZ. Chronic administratioii of $\mathrm{CCK}-\mathrm{PZ}$ was associated with increases in RNA, protein, and DNA content and $\left[{ }^{14} \mathrm{C}\right]$ thymidine incorporation into DNA. On the other hand, chronic administration of bethanechol chloride, an analogue of acetylcholine, was associated with increases in protein content but not DNA content or rates of DNA synthesis. It is recognized that both acetylcholine and pancreozymin augment pancreatic secretion as well as protein and RNA synthesis $(1,4)$. Thus, the ability of CCK-PZ to augment DNA synthesis seems to be a primary distinguishing feature between the polypeptide hormone and acetylcholine.

These studies do not indicate what cells were involved in DNA synthesis. It was assumed since acinar cells represent the bulk of pancreatic tissue and since CCK-PZ specifically acts on these cells that these were the cells responsible for increases in $\left[{ }^{14} \mathrm{C}\right]$ thymidine incorporation into DNA. Standard morphologic studies utilizing hematoxylin- and eosin-staining techniques demonstrated no evidence of inflammatory changes in either saline-, bethanechol-, or pancreozymin-treated groups. Auto- radiographic studies are underway to better identify the populations of cells involved in DNA synthesis.

Whether or not these experimental data derived from laboratory animals can be applied to man remains to be determined. However, there are several clinical situations where information concerning pancreatic cellular integrity, growth, and regeneration may be applicable. These are as follows: (a) pancreatic insufficiency observed after gastrectomy and vagotomy; $(b)$ chronic pancreatitis; and $(c)$ pancreatic carcinoma.

These studies add another dimension to our understanding of the role of CCK-PZ in pancreatic function. It is now recognized that the polypeptide hormone, $\mathrm{CCK}-\mathrm{PZ}$, initiates secretion, initiates metabolic responses, and initiates growth and regeneration. That these responses are not observed with bethanechol chloride administration suggests that secretion alone does not act to enhance cell growth. Thus, merely "working the cell" does not lead to cell growth. Cell growth seems to be initiated via a positive action of hormonal substances.

\section{ACKNOWLEDGMENTS}

The authors wish to acknowledge the secretarial and research assistance of Mrs. Elizabeth Spainhour.

This study was supported by Veterans Administration and National Institutes of Health Grant AM13131-05.

\section{REFERENCES}

1. Morisset, J. A., and P. D. Webster. 1971. In vitro and in vivo effects of pancreozymin, urecholine, and cyclic AMP on rat pancreas. Am. J. Physiol. 220: 202.

2. Stening, G. F., and M. I. Grossman. 1969. Gastrinrelated peptides as stimulants of pancreatic and gastric secretion. Am. J. Physiol. 217: 262.

3. Webster, P. D., L. D. Gunn, and M. P. Tyor. 1966. Effect of in vivo pancreozymin and methacholine on pancreatic lipid metabolism. Am. J. Physiol. 211:781.

4. Webster, P. D., III. 1969. Effect of stimulation on pancreatic amylase secretion and nuclear RNA synthesis. Proc. Soc. Exp. Biol. Med. 132 : 1072.

5. Opie, E. L. 1932. Cytology of the pancreas. In Special Cytology. E. V. Cowdry, editor. Vol. 1, Sect. X. Paul B. Hoeber, Inc., New York. 2nd edition. 375.

6. Leblond, C. P., and B. E. Walker. 1956. Renewal of cell populations. Physiol. Rev. 36: 255.

7. Fitzgerald, P. J., L. Herman, B. Carol, A. Roque, W. H. Marsh, L. Rosenstock, C. Richards, and D. Perl. 1968. Pancreatic acinar cell regeneration. I. Cytologic, cytochemical and pancreatic weight changes. Am. J. Pathol. 52: 983.

8. Fitzgerald, P. J., K. Vinilchaikui, B. Carol, and L. Rosenstock. 1968. Pancreatic acinar cell regeneration. III. DNA synthesis of pancreas nuclei as indicated by thymidine- $\mathrm{H}^{3}$ autoradiography. Am. J. Pathol. 52: 1039.

9. Lehv, M., and P. J. Fitzgerald. 1968. Pancreatic acinar cell regeneration. IV. Regeneration after surgical resection. Am. J. Pathol. 53: 513. 
10. Ham, W. E., R. M. Sandstedt, and F. E. Mussehl. 1945. The proteolytic inhibiting substance in the extract from unheated soy bean meal and its effect upon growth in chicks. J. Biol. Chem. 161: 635 .

11. Chernick, S. S., S. Lepkovsky, and I. L. Chaikoff. 1948. A dietary factor regulating the enzyme content of the pancreas: changes induced in size and proteolytic activity of the chick pancreas by the ingestion of raw soy-bean meal. Am. J. Physiol. 155: 33.

12. Booth, A. N., D. J. Robbins, W. E. Ribelin, and F. DeEds. 1960. Effect of raw soybean meal and amino acids on pancreatic hypertrophy in rats. Proc. Soc. Exp. Biol. Med. 104 : 681.

13. Leroy, J. L., J. A. Morisset, and P. D. Webster. 1971. Dose-related response of pancreatic synthesis and secretion to cholecystokinin-pancreozymin. J. Lab. Clin. Med. 78: 149 .

14. Morisset, J. A., and P. D. Webster. 1972. Effects of fasting and feeding on protein synthesis by the rat pancreas. J. Clin. Invest. 51: 1.

15. Webster, P. D. 1968. Effect of methacholine on pancreatic amylase synthesis. Gastrocnterology. 55: 375.

16. Webster, P. D., and M. P. Tyor. 1966. Effect of intravenous pancreozymin on amino acid incorporation in vitro by pancreatic tissue. Am. J. Physiol. 211: 157.

17. Schmidt, G., and S. J. Thannhauser. 1945. A method for the determination of desoxyribonucleic acid, ribonucleic acid, and phosphoproteins in animal tissues. J. Biol. Chem. $161: 83$.

18. Schneider, W. C. 1945. Phosphorus compounds in animal tissues. I. Extraction and estimation of desoxypentose nucleic acid and of pentose nucleic acid. J. Biol. Chem. 161: 293.

19. Webster, P. D., and M. P. Tyor. 1967. Effects of fasting and feeding on uridine $-{ }^{3} \mathrm{H}$ incorporation into RNA by pancreas slices. Am. J. Physiol. 212: 203.

20. Volkin, E., and W. E. Cohn. 1954. Estimation of nucleic acids. Methods Biochem. Anal. 1: 287.
21. Schneider, W. C. 1957. Determination of nucleic acids in tissues by pentose analysis. Methods. Enzymol. 3: 680.

22. Gornall, A. G., C. J. Bardawill, and M. M. David. 1949. Determination of serum proteins by means of the biuret reaction. J. Biol. Chem. 177: 751.

23. Patterson, M. S., and R. C. Greene. 1965. Measurement of low energy beta-emitters in aqueous solution by liquid scintillation counting of emulsions. Anal. Chem. $37: 854$.

24. Gentry, G. A., P. A. Morse, Jr., D. H. Ives, R. Gebert, and V. R. Potter. 1965. Pyrimidine metabolism in tissue culture cells derived from rat hepatomas. II. Thymidine uptake in suspenson cultures derived from the Novikoff hepatoma. Cancer Res. 25: 509.

25. Plagemann, P. G. W., and J. Erbe. 1972. Thymidine transport by cultured Novikoff hepatoma cells and uptake by simple diffusion and relationship to incorporation into deoxyribonucleic acid. J. Cell Biol. 55: 161.

26. Johnson, L. R., D. Aures, and L. Yuen. 1969. Pentagastrin-induced stimulation of protein synthesis in the gastrointestinal tract. Am. J. Physiol. 217: 251.

27. Chandler, A. M., and L. R. Johnson. 1972. Pentagastrinstimulated incorporation of ${ }^{14} \mathrm{C}$-orotic acid into $\mathrm{RNA}$ of gastric and duodenal mucosa. Proc. Soc. Exp. Biol. Mcd. 141: 110

28. Green, G. M., and R. L. Lyman. 1971. Chymotrypsin inhibitor stimulation of pancreatic enzyme secretion in the rat. Proc. Soc. Exp. Biol. Med. 136: 649 .

29. Green, G. M., and R. L. Lyman. 1972. Feedback regulation of pancreatic enzyme secretion as a mechanism for trypsin inhibitor-induced hypersecretion in rats. Proc. Soc. Exp. Biol. Med. 140: 6.

30. Rothman, S. S., and H. Wells. 1967. Enhancement of pancreatic enzyme synthesis by pancreozymin. Am. J. Physiol. 213: 215.

31. Mayston, P. D., and J. A. Barrowman. 1971. The influence of chronic administration of pentagastrin on the rat pancreas. Q.J. Exp. Physiol. 56: 113 . 